\title{
Leibniz's Concept of Agens in Matter, Space, and Image
}

\section{The Metaphysical Force of Nature}

Gottfried Wilhelm Leibniz rejected the separation of res cogitans and res extensa that his esteemed rival René Descartes had declared the basis of all philosophy as an assumption that was incompatible with nature. His New System written in the mid-1690s on the relation between soul and body and the interactions of all substances represents the most concise exposition of his counterargument on dualistic modes of thought. According to this argument, "the efficient cause of physical actions arises from metaphysics." ${ }^{1}$ Leibniz's considerations on the relation between movement and impetus go straight to the heart of the discussion about a general principle of intrinsic activities that proponents of a 'new materialism' associate with the concept of 'agency.' With all due appreciation for these endeavors, what is troubling here is that the historical derivation of this 'materialism' remains largely tied to a history of ideas. And more seriously still: with Leibniz, an author who like almost no other researcher and philosopher before or since understood the question of a moving substance in matter itself as a key to understanding the world as such has with few exceptions been largely ignored [Ellenzweig and Zammito 2017; Laerke 2017].

The question of the perhaps insoluble problem of the interpenetration of matter and spirit was Leibniz's lifelong theme. In a letter written a year before his death to his trusted correspondent Nicolas Remond, his fundamental conviction was summarized in the formulistic proposition that "everything in nature happens mechanically and at the same time metaphysically but [...] the source of mechanics is in metaphysics" [Leibniz 1969d, p. 655]..$^{2}$ As opposed to the transcendental understanding of this term, this "metaphysics" for Leibniz lies in the autonomous activity of nature, which he identifies

1 "je trouve que la cause efficiente des actions physiques est du resort de la metaphysique" [Leibniz 1978 (1880a), p. 472]; see: [ibid., p. 108]. Unless stated otherwise, all the translations from French and Latin were made by Benjamin Carter.

2 "que tout se fait mechaniquement et metaphysiquement en même temps dans les phenomenes de la nature, mais que la source de la Mechanique est dans la Metaphysique” [Leibniz 1978 (1887), p. 607]; see: [Leibniz 1989a, p. 322; German trans.: p. 323].

Acknowledgment: The author would like to thank Benjamin Carter for translating this text from German. The author acknowledges the support of the Cluster of Excellence 'Matters of Activity. Image Space Material' funded by the Deutsche Forschungsgemeinschaft (DFG, German Research Foundation) under Germany's Excellence Strategy - EXC 2025 - 390648296. 
with the central terms 'form' and 'force.' In his text De ipsa natura sive de vi insita actionibusque Creaturarum, published in 1698 - one of the first to use the term 'monad' he remarks: "there is a certain efficacy residing in things, a form or force such as we usually designate by the name nature" [Leibniz 1969b, p. 501]. ${ }^{3}$ Things contain formam vel vim; with this pairing of form and force, he establishes a general principle.

In one of his texts aimed against Descartes, "Nullum quidem librum [...]," written in May 1702, Leibniz defines this combination as a latently unstable force, since within a permanently changing universe it has a framework that due to its mobility can be thought as infinite: "Moreover, this [...] elastic force, inherent in every body, shows that there is internal motion in every body as well as a primitive and (so to speak) infinite force, although in collision itself it is limited [determinetur] by derivative force as circumstances demand" [Leibniz 1989d, p. 255]. ${ }^{4}$

Leibniz's examples are the arch, a taut string, and compressed air:

For, just as in an arch, each part sustains the full force of that which puts weight on it, and just as, in a taut string, each part sustains the full force of that which tightens it, and just as each portion of compressed air has as much force as the weight of the air pressing down, so too each and every corpuscle is aroused into action by the combined force of the entire surrounding mass, and awaits only an occasion for exercising its power, as the example of gunpowder shows. ${ }^{5}$

[Ibid., pp. 255-256]

Things tremble quasi-elastically between rigidity and explosion.

In the same text, one also finds the definition of conatus as a universal "drive," a "tendency to action" [ibid., p. 252], ${ }^{6}$ which is expressed as an inner urge to move. ${ }^{7} \mathrm{Na}$ ture as a whole is conatus, desiring movement. This is not directed toward a given telos that should be presupposed and attained; it is itself already the perfection that this has as its goal. Internal impetus is the nature of completion [Myrdal 2012, pp. 95-96]. ${ }^{8}$

3 "jam concedendum est, quandam inditam esse rebus efficaciam, formam vel vim, qualis naturae nomine a nobis accipi solet” [Leibniz 1978 (1880c), p. 507].

4 "Ipsa autem vis Elastica omni copori insita ostendit, omni etiam corpori motum intestinum inesse et vim primitivam (ut ita dicam) infinitam, licet in ipso concursu, circumstantiis exigentibus vi derivativa determinetur” [Leibniz 1978 (1880a), p. 399].

5 "ut enim in fornice incumbentis aut in chorda tensa trahentis totam vim quaevis pars sustinet et quaevis portio aeris comprssi tantam vim habet quantam aeris incumbentis pondus, ita quodvis corpusculum totius massa ambientis vi conspirante ad agendum solicitatur nec nisi occasionem exercendae potentiae expectat, ut pulveris pyrii exemplo patet” [Leibniz 1978 (1880a), p. 399].

6 "Vis activa [...] involvit conatum seu tendentiam ad actionem" [Leibniz 1978 (1880a), p. 395].

7 "non tantum corpus praesenti sui motus momento inest in loco sibi commensurato, sed etiam conatum habet seu nisum mutandi locum, ita ut status sequens ex praesenti, per se, naturae vi consequatur" [Leibniz 1978 (1880c), p. 513]. On the derivation of this idea from the winter of 1670-1671: [Mercer 2001, pp. 273-299]; see: [Myrdal 2012, p. 35].

8 On the definition of conatus in the Monadologie, cf. [Bredekamp 2008, p. 111]. In this sense, conatus has an all-encompassing power, and thus possesses a property that Leibniz with a view to Spinoza paradoxically negates [Myrdal 2012, p. 99]. On Spinoza's concept of conatus, see: [Carriero 2011, pp. 69-92]. 
Conatus is linked with the concept of appetition as the idea of an all-pervasive agens. As Leibniz remarks in the Monadologie, "Souls act according to the laws of final causes through their appetitions, ends, and means" [Leibniz 1969c, p. 651, par. 79]. ${ }^{9}$ This concept initially takes up the Aristotelian 'final causes' as a teleological explanation for actions of all kind [Aristotle 1995, pp. 31-32, 194b23-195a3], but objects in principle to the idea of an autarkic, physically determined world, since this systematically raises the question of the cause, that is, of the 'why?' [Mercer 2001, p. 77]. Appetition, however, acts even before the determination of ends and the means to attain these ends. It has no concrete trigger, but is the principle of desire and longing as such. This basic assumption, which is as far as conceivably possible from Descartes' worldview, is related to matter, space, and image - which will be addressed in the following sections.

\section{Leibniz's Active Matter}

Aristotle also ascribed an internal motion to nature, a drive. The agens drives, for instance, the growth of seeds in their transformation into grain [Aristotle 1995, pp. 191-192, 1049b]. However, Leibniz's concept of agens does not mean the striving after a defined goal, but motion itself. Rather than as a means to an external end, it is defined as a continuous impulse that overcomes inertia. In this sense, it is an autonomous, original activity inscribed in the nature of a thing. Instead of Aristotle's original individualities, which carry the urge to completion - the first entelechies [ibid., pp. 191-195; Myrdal 2012, p. 40] - within themselves, Leibniz in the Journal des Savants (June 1695) postulates "primitive forces," which should not be understood as purposive executive bodies or extensions of possibilities. Rather, as "original activity," they carry their determination of essence within themselves: "Aristotle calls them first entelechies. I call them, more intelligibly perhaps, primitive forces, which contain not only the actuality or the completion of possibility but an original activity as well” [Leibniz 1969a, p. 454]. ${ }^{10}$ Whereas for Aristotle, the active form of the first, primitive, force represents a process toward perfection, for Leibniz this is a limitation, since it restricts the potentiality of all merely possible developments [Myrdal 2012, pp. 41, 47-48, 86, 91].

The conviction that a continuously renewing force must be given not as an external addition or subsequent restocking but as immediate nature motivated Leibniz's

9 "Les âmes agissent selon les loix des causes finales par appetitions, fins et moyens" [Leibniz 1998, pp. 56-57, par. 79].

10 "Aristote les apelle entelechies premieres, je les apelle peutestre plus intelligibilment forces primitives, qui ne contiennent pas seulement l'acte ou le complement de la possibilité, mais encor une activité originale” [Leibniz 1978 (1880b), p. 479]; see: [Rozemond 2009, p. 298]. 
attempt to describe and establish a universally operative activity. In a letter from 1698, he remarks that each creature possesses "the force of action that, according to my conception, constitutes the nature of substance. So much so that this value bestowed by God is indeed the energy or force that is given to things." 11 This remark contains the eminent element of Leibniz's considerations. His definition of a force linked with bodies - an agens, an appetition, a conatus - extends to the rebus, the "things"; to these too this movens is given, and in this way the sphere of matter is conceived in an elementary way.

\section{Leibniz's Active Spaces}

The almost unsurpassable radicality of Leibniz's theory of perception lies in the fact that it pushes the interaction between external impulse and internal, autonomous activity to a point at which responses in the form of active resonances are formed even when external impulses are no longer consciously perceived. This has repercussions for the conception of active spaces.

One of Leibniz's examples, which he names in his Nouveaux Essais sur L'Entendement Humain, completed in 1704, is the constant motion of water in the ebb and flow of waves. Although after a certain time someone who is exposed to this will no longer hear it due to the constant repetition, the rhythmic rise and fall of the sound conveys the laws of ebb and flow and with them the movements of the moon and, further, the rules of cosmic consistency, namely "those impressions which are made on us by the bodies around us and which involve the infinite; that connection that each being has with all the rest of the universe" [Leibniz 1996, p. 55]. ${ }^{12}$

Like his antipode Descartes, Leibniz believed in a cosmos suffused with ether, a fine, transparent dust that was thought to bear the forces that keep the planets and stars in their orbits and positions (Fig. 1) [Kemp 2000, p. 38]. For Leibniz, as for many of his contemporaries, Newton's gravitational force was the expression of an unverifiable action at a distance: an occult anathema. Who is right here can only be decided once it has been determined what the $95 \%$ of the universe is made up of that has been given the name dark matter or dark energy. What is decisive is that the interconnectedness of the universe affords the 'small perceptions' (petites perceptions) extensive knowledge even before the reflection apparatus of the concepts can be started up. This marks the most far-reaching theory of preconceptual knowledge ever formulated.

11 "cui etiam agendi vis inest, quae ut ego arbiter substantiae naturam constituit, adeo ut valor ille a Deo tributus revera sit vigor seu vis indita rebus" [Leibniz 1863, p. 239]; see: [Myrdal 2012, p. 85]. 12 "ces impressions que des corps environnans font sur nous, qui enveloppent l'infini, cette liaison que chaque estre a avec tout le reste de l'univers" [Leibniz 1985, p. XXIV, German trans.: p. XXV]. 


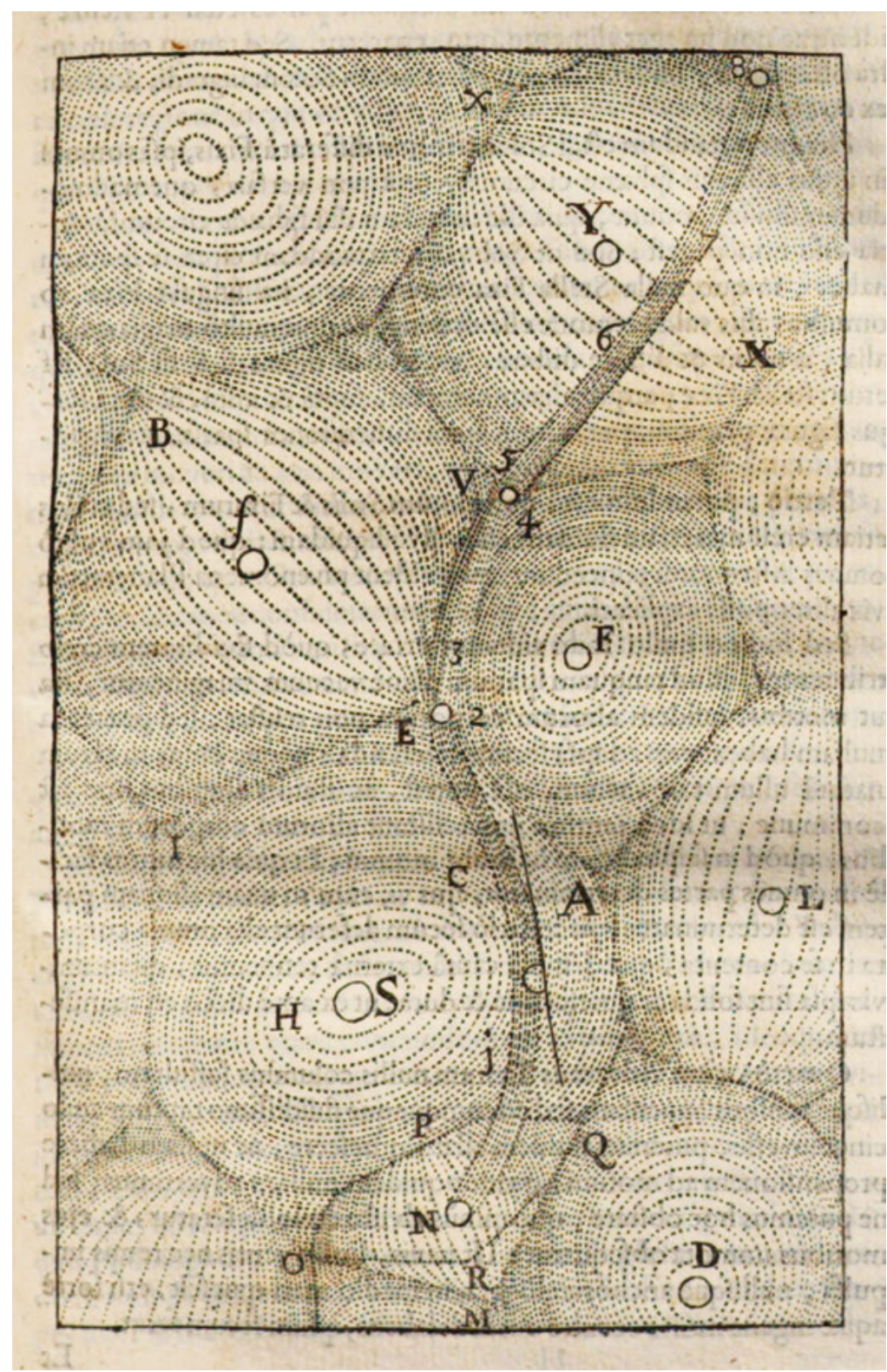

Fig. 1: René Descartes, ether-suffused cosmos, 1644. From: [Descartes 1664, p. 55]. Staatliche Bibliothek Regensburg, 999/Philos.430, p. 55, urn:nbn:de:bvb:12-bsb11109300-6.

The experience of the correspondence between the body and the shifting string spaces gives rise to small perceptions of their interaction. In this connection, the small perceptions are linked with the inner activity in the experience of space, whether in 
open nature or architecture, in landscapes or buildings. This interaction is of decisive importance for Leibniz's definitions of body and space. While, as indivisible units of creation, monads are spirit beings, they necessarily have a receptively agile body. For Hubertus Busche, this explains the "psychophysical expressionism" of all material substances. ${ }^{13}$ The monads are shimmering perceptual instances that create their own means of disclosing, disseminating, and communicating the knowledge to be developed in them. ${ }^{14}$ My consideration that the apparently autarkic, windowless monads necessarily dispose of windows [Bredekamp 2008] has been developed by Wolfram Hogrebe in his observation that it is not the case that monads do not have windows; rather, they are windows [Hogrebe 2013, p. 13]. It is the appetition that gives the monads a drive, a desire, which is responsible for all sensory motions and for the incessant motion in the universe [Leibniz 1969c, p. 644, par. 15; Leibniz 1998, par. 15, pp. 16-17; Bredekamp 2012, p. 89].

On February 25, 1716, Leibniz sent his third letter to Samuel Clark, a colleague and confidant of Newton's. This letter clearly reveals Leibniz's bitterness over the accusations of Newton's supporters that it was Newton and not Leibniz who founded infinitesimal calculus. In his counterattack, Leibniz accuses Newton of the assumption of a fixed, stable space that is a "real absolute being." According to Leibniz, this would lead to "great difficulties" [Leibniz 1969e, p. 682]. ${ }^{15}$ To this he opposes a relationality of space and time: "As for my own opinion, I have said more than once that I hold space to be something merely relative, as time is: that I hold it to be an order of co-existence as time is an order of successions" [ibid.]. ${ }^{16}$ With the conviction that time and space interact in a reciprocal relationalism, Leibniz's conviction of an all-pervasive agens deepened.

This is of decisive importance for Leibniz's definition of the perception of space. If without motion neither space nor time is able to exist, inertia has to be overcome in order to bring both phenomena into existence. The inertia-negating "original $a c$ tivity" quoted above appeared as a disturbance. Without deviation, which disturbs the stability of the geometric pattern, there can be no motion. Force is tendency in a double sense: as interest and appetition - in the sense of a tendency-toward and a deviation-from. ${ }^{17}$ Internal force as appetition and conatus is synonymous as inclination: as deviating difference.

13 See for "psychophysischen Expressionismus," [Busche 1997, pp. 525-529; p. 59, fig. 1]. An early and subsequently forgotten argumentation was developed by Walter Feilchenfeld [Feilchenfeld 1923]. 14 For seminal studies, see: [Busche 1997; Pape 1997].

15 “Ces Messieurs soutiennent donc, que l'Espace est un ètre reel absolue; mais cela les mene à de grande difficultés [...]” [Leibniz 1989b, p. 370, German trans.: p. 371].

16 "Pour moy, j’ay marqué plus d'une fois, que je tenois l'Espace pour quelque chose de purement relatif, comme le Temps; pour un ordre des Coexistences, comme le temps est un ordre de successions" [Leibniz 1989b, p. 370, German trans.: p. 371]; see: [Bredekamp 2008, p. 112].

17 "aliud est multoque plus continet rem non esse indifferentem sed vim habere et velut inclinationem ad statum retinendum atque adeo resistere mutanti” [Leibniz 1989c, p. 126, German trans.: p. 127]; see: [Myrdal 2012, p. 103]. 


\section{Leibniz’s Active Images}

This principle can also finally be applied to 'active images,' which are central to the concept of 'image acts.' They have a long tradition that goes back to the ancient rhetorical teaching of imagines agentes, which while first appearing as mental images acquire an objective status through their power to act - and in this way also frame materially formed images [(Anonymous). Rhetorica ad Herrenium 1994, p. 176].

The status of images as a lively and thus active instance was developed by Leibniz in an inimitable way in his interpretation of the brain. In his Nouveaux Essais sur L'Entendement Humain, he imagines a room in which a screen has been stretched [Leibniz 1996, p. 144; Leibniz 1985, pp. 180-181]. An adequate visualization of this mental image is not yet known. Elements of it can be found in Johann Jakob Scheuchzer's illustration The Silver Cord, in which the brain and spinal cord appear on a giant cloth (Fig. 2). ${ }^{18}$ The Swiss natural scientist was an esteemed friend of Leibniz's. In contrast to Scheuchzer's presentation of the brain on a screen, however, Leibniz's brain is a screen: a painting covered with an infinite number of motifs and above all folded in on itself: "there is a screen in this dark room to receive the images, and [...] it is not uniform but is diversified by folds representing items of innate knowledge" [Leibniz 1996, p. 144]. ${ }^{19}$ With this image, the brain becomes a microcosmic representation of the universe as a sphere folded in on itself, which forces all substances, without leaps, into ever new eddies and gyrations and new enfoldings.

An incomparable imagining of this motif has been created by the artist Giovanni Paolo Schor in his depiction of a Roman parade bed in which heaven and earth are united in a single, densely folded mountain of cloth (Fig. 3) [Karsten 2003, fig. 50; Walker 2007, pp. 154-155]. As if he had such an image before him Leibniz describes the universe as a continuous body that is "not divided but [...] like a tunic folded in various ways."20

Leibniz would have undoubtedly found confirmation for this idea in recent developments in astronomy in which the universe emerges as a vast structure in a permanent process of self-enfolding (Fig. 4). From the same cloth, so to speak, is Leibniz's image of the microcosmic brain as an infinitely folded, intricately painted canvas or screen in the dark chamber of the skull. To the extent that this "screen or membrane, being under tension, has a kind of elasticity or active force" [Leibniz 1996, p. 144], ${ }^{21}$ it develops the inner conatus, which is realized as "a kind of elasticity or active force."

18 See: [Scheuchzer 1731, tab. DXCIII]; reproduced in [Felfe 2003, p. 52, fig. 52].

19 "dans la chambre obscure il y eut une toile pour recevoir les especes, qui ne fut pas unie, mais diversifiée par des plis, représentant les connoissances innées” [Leibniz 1985, p. 180, German trans.: p. 181] (translation modified).

20 "Totum universum est unum corpus continuum. Neque dividitur, sed instar cerae transfiguratur, instar tunicae varie plicatur” [Leibniz 1999, p. 1687, Z. 1-2].

21 "cette toile ou membrane estant tendue, eût une manière de ressort ou force d'agir" [Leibniz 1985, p. 180, German trans.: p. 181]. 


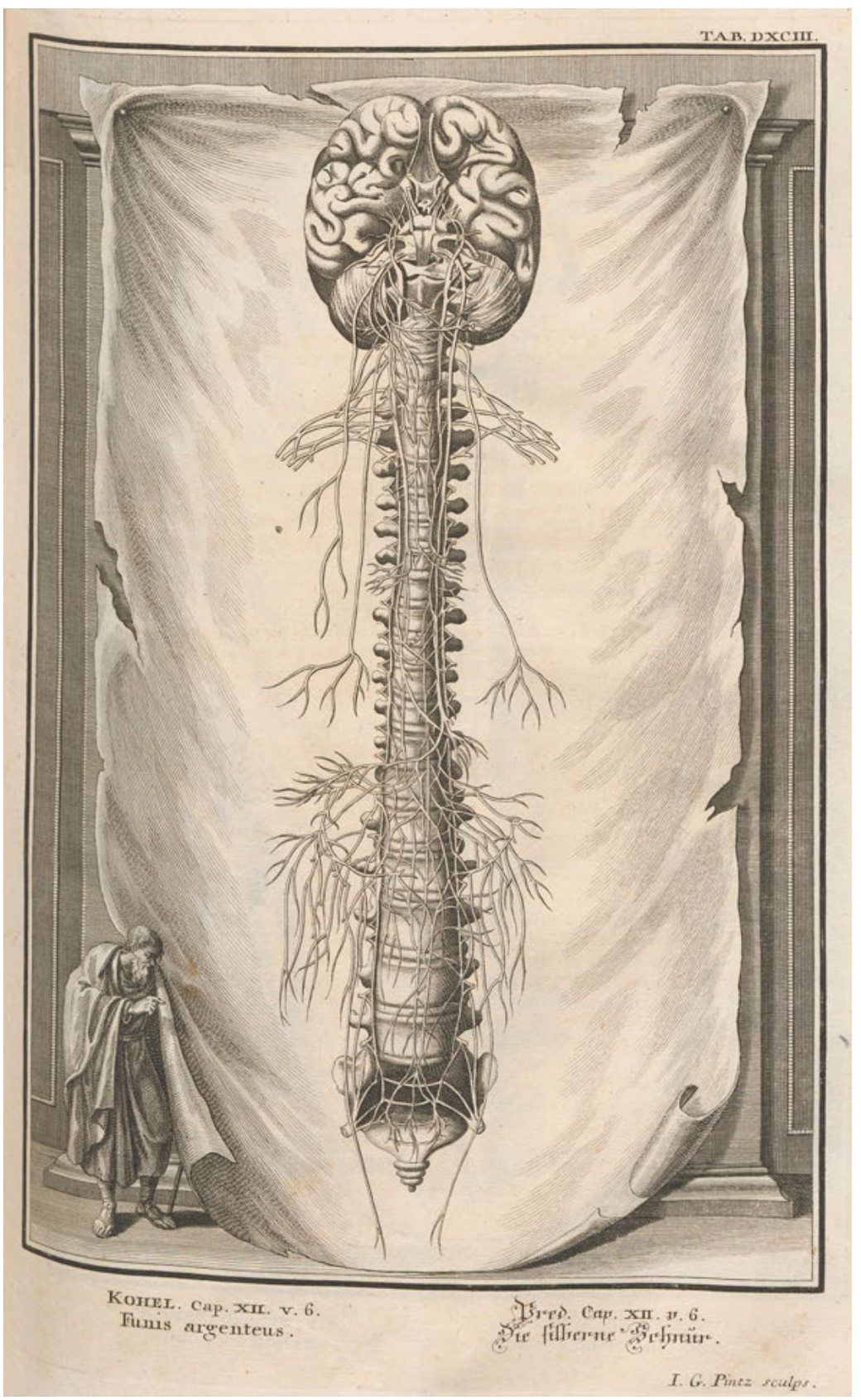

Fig. 2: Johann Georg Pintz after Johann Melchior Füßli, The Silver Cord, 1735, copper engraving. From: [Scheuchzer 1731, tab. DXCIII]. ETH-Bibliothek Zürich, Rar 5864, DOI: 10.3931/e-rara-10140. Public Domain Mark. 


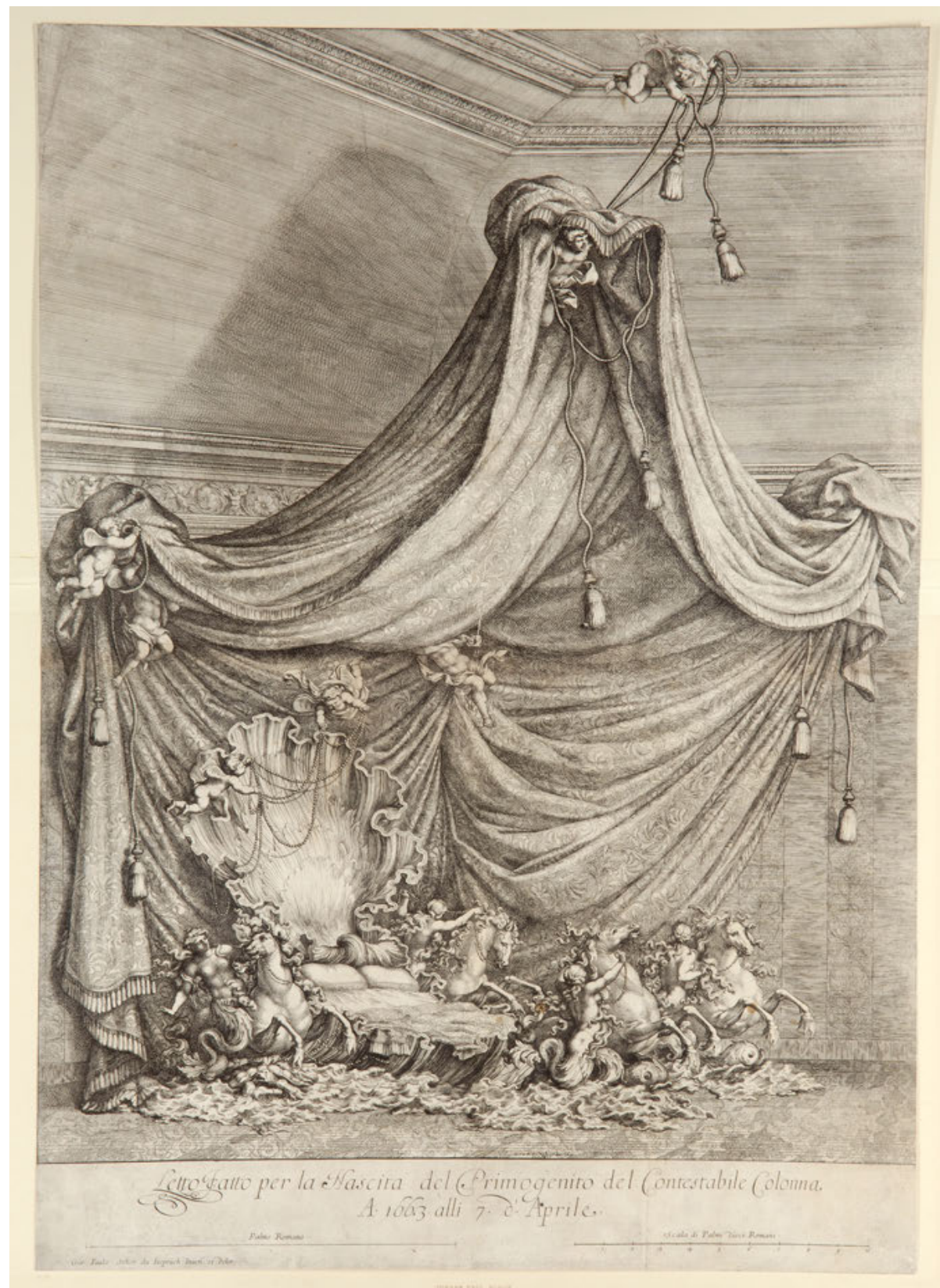

Fig. 3: Giovanni Paolo Schor, design of a bed for Maria Mancini, 1663, copper engraving. Photo (c) Dietmar Katz, bpk, Kunstbibliothek, Staatliche Museen zu Berlin. 
It thereby "acts (or reacts) in ways which are adapted both to past folds and to new ones coming from the impressions of the images" [Leibniz 1996, p. 144]. ${ }^{22}$ In this interplay of old and new images, which causes the screen to vibrate and unfold what is embedded there, lies for Leibniz the dynamics of the images' agency.

But that is not all. To the extent that the screen undergoes constant vibrations and oscillations similar to the sound-producing vibration of a taut string, "vibrations or oscillations" arise "like those we see when a cord under tension is plucked" in such a way that it "gives off something of a musical sound" [Leibniz 1996, p. 145]. ${ }^{23}$ In this passage, the rivalry between the senses and the arts becomes a shared endeavor [Van Gastel, Hadjinicolaou, and Rath 2014]. The central proposition of this image that "the screen which represents our brain must be active and elastic" [Leibniz 1996, p. 145$]^{24}$ - corresponds to the principle of the universal validity of agens.

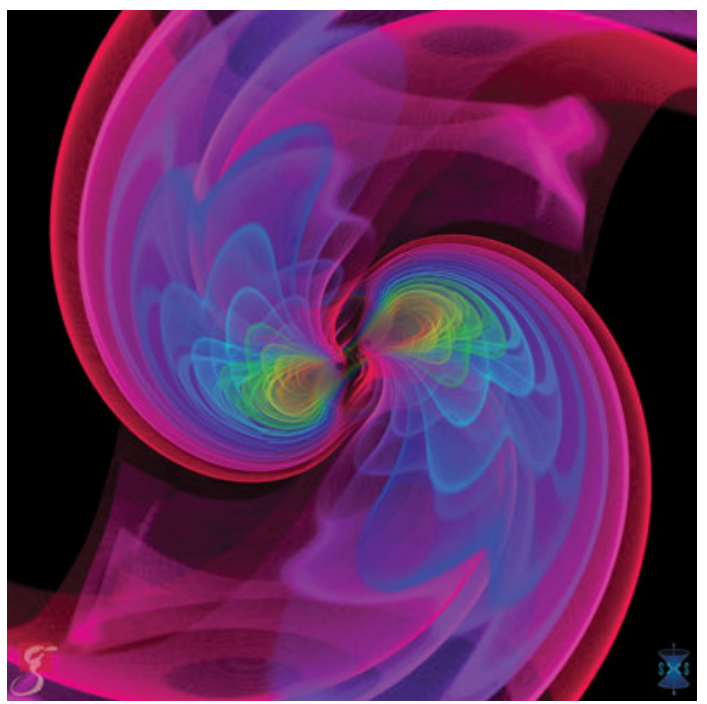

Fig. 4: Simulation of the gravitational waves of a black hole. (c) Serguei Ossokine, Alessandra Buonanno (Max Planck Institute for Gravitational Physics), Simulating eXtreme Spacetimes project, D. Steinhauser (airborne hydromapping).

22 "une action ou réaction accommodée tant aux plis passés qu'aux nouveaux venus des impressions des especes" [Leibniz 1985, p. 180, German trans.: p. 181] (English translation modified).

23 "vibrations ou oscillations, telles qu'on voit dans une corde tendue quand on la touche, de sorte qu'elle rendroit une manière de son musical” [Leibniz 1985, p. 180, German trans.: p. 181]. 24 "la toile qui represente nostre cerveau soit active et elastique" [Leibniz 1985, p. 180, German trans.: p. 181] (English translation modified). 


\section{The Vis Agendi}

Perfection is to be identified with force, the vis agendi [Myrdal 2012, p. 85], which represents a transferal of the imagines agentes to the whole of creation. For Leibniz, what gives things their internal force is God. Of course in our world seemingly purged of religious thought we flinch momentarily at the mention of a 'God' who is supposed to have given things their inherent force. This term retains its validity, however, if it is used as a sign for all phenomena that can be described but not explained: from the question of the cause of gravity to the problem of what preceded the big bang or the riddle of what causes the acceleration of the universe's expansion. One solution has been suggested by Baruch Spinoza with his formula Deus, seu Natura, which equates God with nature [Spinoza 2008, praefatio, pp. 382-383, Z. 24; Wollgast 1999, p. 15 and passim; Jung 2005, p. 131]. ${ }^{25}$ But even if this is rejected one must still reckon, on the level of phenomena, with all that Leibniz has proposed: a universally operative activity given to all creations that presses for connectivity and interaction.

The art lies in taking account of a general activity that - from the gravity supporting the universe to the cohesion of the monads - acts in the microcosmic domain without lapsing into mystification. A sharpened phenomenology could help to avoid this short circuit. Here, nature should not be thought solely as a passivefemale potential for activation that is either subjected to violence or made the object of a peace settlement. Rather, it should be ascribed an active status.

This applies, in particular, to Leibniz and his comprehensive proposal of a force operating in each thing and creature, an acting vector, a cosmic conatus, and a microcosmically operating appetition. Leibniz, who in the context of his own time postulated an autonomously active vis collectively operating in matter, space, and artifacts, and an all-pervasive vigor, has provided us with a standard against which to sharpen the concepts being developed today.

\section{Bibliography}

[Anonymous]. Rhetorica ad Herennium. Ed. and trans. Nüßlein T. München, Zürich, Artemis \& Winkler, 1994.

Aristoteles. Physik: Vorlesung über die Natur. German trans. Zekl HG. In: Aristoteles: Philosophische Schriften in sechs Bänden. Vol. 6. Hamburg, Meiner, 1995.

Aristoteles. Metaphysik. German trans. Bonit H and Seidl H. In: Aristoteles: Philosophische Schriften in sechs Bänden. Vol. 5. Hamburg, Meiner, 1995.

Bredekamp H. Die Fenster der Monade: Gottfried Wilhelm Leibniz' Theater der Natur und Kunst. 2nd edn. Berlin, Akademie Verlag, 2008.

25 The quote is “Deus, seu Natura,” and not as commonly quoted the equivalent 'Deus sive Natura.' 
Bredekamp H. Leibniz und die Revolution der Gartenkunst: Herrenhausen, Versailles und die Philosophie der Blätter. Berlin, Klaus Wagenbach Verlag, 2012.

Busche H. Leibniz' Weg ins perspektivische Universum: Eine Harmonie im Zeitalter der Berechnung. Hamburg, Meiner, 1997.

Carriero J. Conatus and Perfection in Spinoza. Midwest Studies in Philosophy, 2011 (XXXV), 69-92.

Descartes R. Principia Philosophiae. 4th edn. Amsterdam, Elzevir, 1644.

Ellenzweig S, Zammito JH, eds. The New Politics of Materialism: History, Philosophy, Science. London, New York, Routledge, 2017.

Feilchenfeld W. Leibniz und Henry More: Ein Beitrag zur Entwicklungsgeschichte der Monadologie. Kant-Studien 1923, 28, 323-334.

Felfe R. Naturgeschichte als kunstvolle Synthese: Physikotheologie und Bildpraxis bei Johann Jakob Scheuchzer. Berlin, Akademie Verlag, 2003.

Gastel JV, Hadjinicolaou Y, Rath M, eds. Paragone als Mitstreit. Berlin, Akademie Verlag, 2014. Hogrebe W. Der implizite Mensch. Berlin, Oldenburg Verlag, 2013.

Jung M. Spinoza: Gott ist Natur - Natur ist Gott. Lahnstein, EMU-Verlag, 2005.

Karsten A. Künstler und Kardinäle: Vom Mäzenatentum römischer Kardinalnepoten im 17. Jahrhundert. Cologne, Weimar, Vienna, Böhlau, 2003.

Kemp M. Visualizations: The Nature Book of Art and Science. Berkeley CA, University of California Press, 2000.

Laerke M. Materialism, Constructivism, and Political Scepticism: Leibniz, Hobbes, and the Erudite Libertines. In: Ellenzweig S, Zammito JH, eds. The New Politics of Materialism: History, Philosophy, Science. London, New York, Routledge, 2017, 250-268.

Leibniz GW. Leibnizens mathematische Schriften. Vol. 7. Ed. Gerhardt Cl. Berlin, Halle, Schmidt, 1863. Leibniz GW. A New System of the Nature and the Communication of Substances, as well as the Union between the Soul and the Body, 1695. In: Ed. and trans. Loemker LE. Leibniz GW. Philosophical Papers and Letters. 2nd edn. Dordrecht, Boston MA, London, Kluwer Academic, 1969a, 453-459.

Leibniz GW. On Nature Itself, or on the Inherent Force and Actions of Created Things, 1698. In: Ed. and trans. Loemker LE. Leibniz GW. Philosophical Papers and Letters. 2nd edn. Dordrecht, Boston MA, London, Kluwer Academic, 1969b, 498-508.

Leibniz GW. The Monadology, 1714. In: Ed. and trans. Loemker LE. Leibniz GW. Philosophical Papers and Letters. 2nd edn. Dordrecht, Boston MA, London, Kluwer Academic, 1969c, 643-653.

Leibniz GW. Letters to Nicolas Remond, 1714-15. In: Ed. and trans. Loemker LE. Leibniz GW. Philosophical Papers and Letters. 2nd edn. Dordrecht, Boston MA, London, Kluwer Academic, 1969d, 654-660.

Leibniz GW. The Controversy between Leibniz and Clarke, 1715-16. In: Ed. and trans. Loemker LE. Leibniz GW. Philosophical Papers and Letters. 2nd edn. Dordrecht, R. Reidel, 1969e, 675-721.

Leibniz GW. Nullum quidem librum [...]. In: Leibniz GW. Die philosophischen Schriften. Vol. 4. Ed. Gerhardt Cl. Berlin, Weidmann, 1880a, reprint Hildesheim. New York, Georg Olms Verlag, 1978, 393-400.

Leibniz GW. Système nouveau de la nature et de la communication des substances, aussi bien que de l'union qu'il y a entre l'âme et le corps: Erster Entwurf. In: Leibniz GW. Die philosophischen Schriften. Vol. 4. Ed. Gerhardt Cl. Berlin, Weidmann, 1880b, reprint Hildesheim. New York, Georg Olms Verlag, 1978, 471-477.

Leibniz GW. De ipsa natura sive de vi insita actionibusque creaturarum, pro dynamicis suis confirmandis illustrandisque. In: Leibniz GW. Die philosophischen Schriften. Vol. 4. Gerhardt Cl. Berlin, Weidmann, 1880c, reprint Hildesheim. New York, Georg Olms Verlag, 1978, 504-516.

Leibniz GW. Leibniz an Nicolas Remond, 10. 1.1714. In: Leibniz GW. Die philosophischen Schriften. Vol. 3. Gerhardt Cl. Berlin, Weidmann, 1887. reprint Hildesheim. New York, Georg Olms Verlag, 1978, 605-608. 
Leibniz GW. Philosophische Schriften. Vol. 3,1-2. Nouveaux Essais sur l'entendement humain. Neue Abhandlungen über den menschlichen Verstand. Ed. and trans. von Engelhardt W and Holz HH. 2nd edn. Darmstadt, Wissenschaftliche Buchgesellschaft, 1985.

Leibniz GW. 1. Brief an Remond (10.1.1714). In: Leibniz GW. Philosophische Schriften. Vol. 5,2.

Briefe von besonderem philosophischem Interesse. Ed. and trans. Wiater W. Darmstadt, Wissenschaftliche Buchgesellschaft, 1989a, 318-325.

Leibniz GW. Leibniz' drittes Schreiben [an Samuel Clark] (25.2.1716). In: Leibniz GW.

Philosophische Schriften. Vol. 5,2. Briefe von besonderem philosophischem Interesse.

Ed. and trans. Wiater W. Darmstadt, Wissenschaftliche Buchgesellschaft, 1989b, 370-371.

Leibniz GW. 1. Brief an B. de Volder (24.3./3.4.1698). In: Leibniz GW. Philosophische

Schriften. Vol. 5,2. Briefe von besonderem philosophischem Interesse. Ed. and trans. Wiater

W. Darmstadt, Wissenschaftliche Buchgesellschaft, 1989c, 122-133.

Leibniz GW. On Body and Force, Against the Cartesians (1702). In: Leibniz GW: Philosophical

Essays. Ed. and trans. Ariew R and Garber D. Indianapolis, Hackett, 1989d, 250-256.

Leibniz GW. New Essays on Human Understanding. Trans. and ed. Peter Remnant and Jonathan

Bennett. Cambridge, 1996.

Leibniz GW. Monadologie. Ed. and trans. Hecht H. Stuttgart, Reclam, 1998.

Leibniz GW. Sämtliche Schriften und Briefe. Col. VI, vol. 4,B. Ed. Berlin-Brandenburgische Akademie der

Wissenschaften und Akademie der Wissenschaften Göttingen. Berlin, Akademie Verlag, 1999.

Mercer C. Leibniz's Metaphysics: Its Origins and Development. Cambridge, Cambridge University

Press, 2001.

Myrdal P. Leibniz on Agency and Force. Doctoral Thesis, Uppsala University, 2012.

Pape H. Die Unsichtbarkeit der Welt: Eine visuelle kritik neuzeitlicher Ontologie. Frankfurt am Main, Suhrkamp, 1997.

Rozemond M. Leibniz on Final Causation. In: Newlands S, Jorgensen LM, eds. Metaphysics and the Good: Themes from the Philosophy of Robert Merrihew Adams. Oxford, New York, Oxford University Press, 2009, 272-291.

Scheuchzer JJ. Physica Sacra. Vol. 4. Augsburg, Ulm, Johann Andreas Pfeffel, 1731.

Scheuchzer JJ. Kupfer-Bibel, in welcher die Physica Sacra oder geheiligte Naturwissenschafft derer in der Heiligen Schrifft vorkommenden natürlichen Sachen deutlich erklärt und bewährt. Vol. 4. Augsburg, Ulm, Christian Ulrich Wagner, 1735, DOI: 10.3931/e-rara-10140.

Spinoza BD. Ethica. Pars quarta: De servitute humana seu de affectuum viribus. In: Blumenstock K, ed. Baruch de Spinoza: Opera - Werke. Latin/German. Vol. 2. Darmstadt, Wissenschaftliche Buchgesellschaft, 2008, 380-562.

Walker S. "Gantz irregulier”: Ein barocker Betstuhl aus Rom. Barockberichte: Informationsblätter des Salzburger Barockmuseums zur bildenden Kunst des 17. und 18. Jahrhunderts 2007, 48-49, 154-161.

Wollgast S. Deus sive Natura: Zum Pantheismusstreit in der europäischen Philosophie und Religionsgeschichte. Sitzungsberichte der Leibniz-Sozietät 1999, 27 (8), 5-40.

Horst Bredekamp, born 29 April 1947 in Kiel, Germany, studied art history, archaeology, philosophy and sociology in Kiel, Munich, Berlin and Marburg, where he received his PhD in 1974. After an internship at the Liebieghaus in Frankfurt am Main, Germany (1974-1976) he became assistent professor at the university of Hamburg, where he tenured as Professor of Art History in 1982. Since 1993 he has tenured as Professor of Art History at the Humboldt University of Berlin. In addition 2003-2012 he has been a permanent fellow of the Institute for Advanced Study in Berlin (Wissenschaftskolleg zu Berlin). From 2015-2018 he was one of the three founding directors of the Humboldt Forum, Berlin. 
